\title{
Education scholarship in emergency medicine part 2: supporting and developing scholars
}

\author{
Glen Bandiera, MD, MEd*; Constance LeBlanc, MD, MA(Ed) ${ }^{\dagger}$; Glenn Regehr, $\mathrm{PhD}^{\ddagger}$; \\ Linda Snell, MD, MHPE ${ }^{\S}$; Jason R. Frank, MD, MA(Ed)" ; Jonathan Sherbino, MD, MEd
}

\begin{abstract}
Emergency medicine (EM) is defined, in part, by clinical excellence across an immense breadth of content and the provision of exemplary bedside teaching to a wide variety of learners. The specialty is also well-suited to a number of emerging areas of education scholarship, particularly in relation to team-based learning, clinical reasoning, acute care response, and simulation-based teaching. The success of EM education scholarship will be predicated on systematic, collective attention to providing the infrastructure for this to occur. Specifically, as a new generation of emergency physicians prepares for education careers, academic organizations need to develop means not only to identify potential scholars but also to mentor, support, and encourage their careers. This paper summarizes the supporting literature and presents related recommendations from a 2013 consensus conference on EM education scholarship led by the Academic Section of the Canadian Association of Emergency Physicians.
\end{abstract}

\section{RÉSUMÉ}

La médecine d'urgence (MU) se définit, en partie, par l'excellence clinique dans un vaste champ de connaissances et par la prestation d'un enseignement clinique exemplaire à un large éventail d'apprenants. La spécialité se prête bien également à l'allocation de bourses d'études en éducation dans un certain nombre de tout nouveaux domaines, particulièrement en ce qui concerne l'apprentissage en équipe, les résolutions de problèmes cliniques, les réactions en soins actifs, et l'enseignement fondé sur les simulations. Le succès des bourses d'études en éducation, applicables à la MU sera tributaire de l'attention qu'on aura portée collectivement et systématiquement à la mise en place d'une infrastructure appropriée. Plus précisément, à mesure qu'une nouvelle génération d'urgentologues se prépare à embrasser une carrière en éducation, les structures $\mathrm{d}^{\prime}$ enseignement universitaire doivent concevoir des moyens leur permettant non seulement de repérer les chercheursboursiers potentiels, mais aussi de guider, de soutenir et de favoriser leur carrière. L'article présentera un résumé de la documentation à l'appui ainsi que les recommandations en la matière, issues de la conférence de consensus de 2013 tenue par la division Academic de I'Association canadienne des médecins d'urgence, sur les bourses d'études en éducation applicables à la MU.

Keywords: education scholarship, innovation, institutional support

Emergency medicine (EM) is a specialty rooted in clinical education, providing abundant opportunities to be a leader in education scholarship. The nature and definition of scholarship in medical education have evolved over time..$^{1-5}$ Recently, educators have begun to explore the specifics of education scholarship for EM (see Sherbino and colleagues in this issue of $C F E M^{\circ}$ ).

Although clearly defining education scholarship and arguing its rationale are necessary first steps, additional steps are required for EM to become a leading specialty in education scholarship. Local, institutional, and systemic alignment must be sought to encourage and support successful and sustained involvement in scholarship. This paper, one of a series resulting from the 2013 consensus conference on EM education scholarship hosted by the Academic Section of the Canadian Association of Emergency Physicians (CAEP), describes an approach and an array of critical

From the *Department of Medicine, University of Toronto, Toronto, ON; †Department of Emergency Medicine, Dalhousie University, Halifax, NS; $¥$ Centre for Health Education Scholarship, University of British Columbia, Vancouver, BC; §Centre for Medical Education, McGill University, Montreal, QC; $\|$ Department of Emergency Medicine, University of Ottawa, Ottawa, ON; and 'Division of Emergency Medicine, McMaster University, Hamilton, ON.

Correspondence to: Dr. Jonathan Sherbino, McMaster Clinic, Hamilton General Hospital, 237 Barton Street East, Hamilton, ON L8L 2X2; sherbino@ momaster.ca.

This article has been peer reviewed. 
elements needed to stimulate and support EM education scholars. The paper provides a background to frame the issue, summarizes the literature, and presents arguments and recommendations for a course of action.

\section{BACKGROUND}

$\mathrm{EM}$ is a unique specialty in which uncertainty, unpredictability, immense breadth of content, and a shiftwork model combine to provide both challenges and opportunities in education. ${ }^{7-10}$ Clinical EM education, for example, is predicated on a work-based immersive model; therefore, EM faculty are well suited to investigating innovations in this context. Simulation and team-based educational models (especially those focusing on uncertainty and ad hoc teams) are also well aligned with EM practice. Finally, the approach to the undifferentiated patient, the primary focus on diagnosis and early intervention, the close and simultaneous interaction with multiple elements of the health care system, and departmental operations are all core competencies unique to EM and ripe for education scholarship. Many emergency departments ostensibly function as living laboratories for education scholarship.

Numerous perspectives are brought to bear when attempting to define scholarship in education. ${ }^{5,11-13} \mathrm{It}$ is therefore challenging to be categorical about what counts and what does not. Having adopted the highly inclusive Canadian Association for Medical Education (CAME) definition-"Education Scholarship is an umbrella term which can encompass both research and innovation in health professions education. Quality in education scholarship is attained through work that is: peer-reviewed, publicly disseminated and provides a platform that others can build on" attendees at the 2013 CAEP Consensus Conference on EM Scholarship set the foundation on which the EM community can now build programs of innovation and excellence.

As Canadian EM continues to develop and aims to contribute to the field of medical education, individual faculty members will need to actively engage in education scholarship. To do so in an effective and sustained manner, however, these scholars will require meaningful support from their home academic EM units. Thus, issues related to recruitment, support, sustainability, and quality of contribution will arise.
The approaches to these issues will, in turn, be informed by what the specialty sees as its unique contribution to the advancement of education scholarship. The remainder of this paper summarizes a body of literature that potentially supports recommendations around these issues.

\section{SUPPORTING LITERATURE AND RECENT DEVELOPMENTS}

\section{Education scholarship in the EM context}

Many recent reports have called for substantial change in the Canadian medical education context. ${ }^{14-16}$ Thoughtful advancement in the directions specified by such reports will require engagement of faculty in new forms of inquiry and innovation. EM education lends itself to all experimental, applied, and practicebased research. ${ }^{17-19}$

However, there is evidence to suggest that EM still has a way to go to fulfill its academic potential relative to other, more established specialties. For example, EM specialists in one US study received less National Institutes of Health support per active faculty member than did their counterparts in internal medicine, pediatrics, anesthesiology, and family medicine, prompting calls for continued efforts to develop EM clinician investigators. ${ }^{20}$ At least in Canada, there are likely several factors contributing to this situation. The following sections articulate some of the challenges faced by EM as a profession and by individuals within the profession.

\section{Defining and recognizing education scholarship as a mandate}

Having a critical mass of education scholars is a key to success. ${ }^{21,22}$ Whether this pertains to mentorship, departmental support, faculty development, multisite innovations, or peer-to-peer networking, the pervasive message is that scholarship is a group activity.

Dirks wrote: "There is little that brings greater honor to a college or university faculty member than reputation as a scholar." ${ }^{\prime}$ Such contributions must nevertheless be externally recognized..$^{23}$ More than ever, faculties of medicine are explicitly recognizing education scholarship as a legitimate means to academic advancement. In the recent CAME position paper on scholarship, all 17 medical schools in Canada had some means to recognize education scholarship, 
although only about half made explicit reference to it as a promotion strategy. ${ }^{5}$ This pattern is true across North America, where there can still be found examples where the value of educational scholarship is less than other traditional means of academic contribution (e.g., clinical research). ${ }^{24,25}$

Universal challenges to conducting and publishing education scholarship include insufficient training in metholodogy, inadequate protected time from other departmental responsibilities, inadequate funding, lack of mentorship, insufficient networking or a need for high participant numbers to complete a project, and a lack of journal support for education scholarship. $^{26}$

\section{Developing expertise}

EM practitioners in Canada arrive in academic positions from a variety of routes, including certified training in Canada or abroad, and various forms of practice eligibility. With respect to Canadian training options, the 5-year Royal College of Physicians and Surgeons specialist program may have greater potential to prepare future EM academics compared to the alternative 3-year Canadian College of Family Physicians (CCFP) specialty competency program, by virtue of the curriculum and the duration of training. Indeed, those selecting the 5 -year program cite the subspecialty and teaching opportunities available as attractive features..$^{27}$ However, despite the potential academic preparation differences between programs, many CCFP(EM) graduates practice in academic-affiliated hospitals (as many as $75 \%$ of graduates from one CCFP(EM) program..$^{28}$

This has important implications for preparing EM physicians to be successful academics. The literature indicates that formal training makes a difference to academic success. In one study, fellowship-trained primary care physicians had more success with publications and promotions. ${ }^{29}$ Similar findings can be found related to career satisfaction; it was higher in surgeons who had done an academic fellowship compared to those who had not. ${ }^{30}$ Other studies have shown that early success (e.g., during training) predicts long-term success as an academic, suggesting that recruitment decisions for academics should be informed by a formal track record and training in the academic area of interest. ${ }^{31}$ Despite the need, only one example of a North American EM specific education fellowship was identified in a recent study. ${ }^{32}$
Faculty without medical education training who wish to pursue education scholarship as a career track should be encouraged and supported to pursue graduate or fellowship training., .,33 Particular to EM, brief programs targeting specific skills have shown changes in behaviour and increased scholarly output. ${ }^{34-36}$ In one study, the specific skills identified were research methods, mentorship and career counselling, leadership skills, scholarly writing, knowledge of the faculty development process, and physician wellness. ${ }^{37}$

Although the number of publications in medical education research continues to increase, there are still significant barriers and limitations that affect both the output and the quality of these studies. ${ }^{38-41}$ An expert American panel recommended greater sophistication in EM faculty development, urging programs to consider a stronger emphasis on the principles of educational scholarship; the process of mentoring for those interested in enhancing their productivity; and flexible models of delivery that are multidisciplinary, team oriented, global in scope, adaptive to different types of learners and to new technology, and grounded in the theories and principles of learning. ${ }^{42}$

\section{Supporting ongoing success}

van Melle and colleagues identified several institutional enablers to the ongoing success of education scholars: a supportive department head, mentors, a department education committee, a departmental education coordinator or departmental peer review committee, and formal education programs. ${ }^{5}$ Mentorship has been shown to increase the likelihood of an individual selecting an academic career and, once that selection has been made, to improve academic career productivity, satisfaction, and longevity. ${ }^{43-50}$ Furthermore, faculty development programs have been shown to improve mentoring skills. ${ }^{51}$ There is once again evidence that EM has not fully embraced the importance of mentorship. In a large American survey, the impact of mentors and role models in the EM group was significantly lower than the other comparison groups. ${ }^{52}$

Prospective scholars also require protected time to be productive. This means not only a financial plan to support nonclinical academic work but also leaders willing to protect scholars from the systematic erosion of their time by pressing clinical and administrative duties. The recommended amount of time required for effective scholarship varies from a minimum of 40 to 
$50 \%$ of a full-time equivalent (FTE) position per week, whereas standard clinician-scientist models require up to $80 \%$ protected time. ${ }^{53-55}$ Furthermore, young scholars should be provided with adequate start-up funding and access to expert assistance, such as statisticians, methodologists, and project managers, to allow them to establish a track record without the burden of trying to secure outside salary or operational funding. ${ }^{53}$ Common pitfalls included distribution of protected time across large numbers of faculty, inadequately protecting any of them, inappropriately high clinical load, investing in individuals without proper formal training, and poorly established benchmarks or job descriptions. ${ }^{53}$

\section{Anticipating emerging challenges}

Generational cohorts have different values with regard to work-life balance, academic and personal motivators, desire for control over their work, and effective productivity incentives. ${ }^{56}$ These differences may be amplified in EM as many choose the specialty because of the control it affords over personal time. ${ }^{27}$ Many attracted to EM value the discrete time for work and personal time and may not be predisposed to longitudinal projects or scholarship infrastructure. Academics typically have accepted the notion of "working more and making less" than nonacademic physicians, a notion that is thought to appeal less to younger generations. ${ }^{57} \mathrm{New}$ generations are noted to value flexibility, control over their time, and much broader conceptualizations of what should be valued. 57,58

Although collaborative scholarship is emerging as the dominant process of the near future, academic advancement structures still reward the individual effort. $5,59,60$ The EM community needs to champion (and reward) networks as a means to answer important education questions and share innovations particular to our specialty. ${ }^{61}$ Initiatives such as networks of EM educators meeting at national conferences, Web-based collaborations, and local interdisciplinary education networks can allow junior faculty to engage with potential collaborators.

\section{RECOMMENDATIONS}

In 2013, the Academic Section of the CAEP held a consensus conference on education scholarship.
Through a process that included a review of the literature, expert thematic analysis, and iterative consensus agreement, the following recommendations were supported:

\section{SUPPORTING EM EDUCATION SCHOLARSHIP}

1. Academic divisions/departments of EM should develop education scholars.

- Action Item: Academic divisions/departments of EM should develop (or adopt where already existing locally) defined positions for education scholars.

- Action Item: The Academic Section should support academic EM leadership to negotiate funding and support to recruit and/or develop education scholars.

- Action Item: Academic divisions/departments of EM should support involvement in advanced training programs to develop education scholars. The training programs should permit an emphasis on EM-specific issues. Flexible delivery models, adaptable to individual needs, are required.

- Action Item: The Academic Section should promote education scholarship among EM trainees to permit them to consider this academic path.

2. Academic divisions/departments of EM should support education scholarship.

- Action Item: The Academic Section should develop metrics and collect data to produce an inventory of current scholarship in EM in Canada.

- Action Item: Academic divisions/departments of EM should establish meaningful financial support and protected time for education scholars. Education scholars with protected time should be shielded from competing demands on time and intellectual resources (e.g. limits on clinical and administration activities).

- Action Item: Academic divisions/departments of EM should establish operational and infrastructure funding to education 
scholars early in their career. This funding should be in place for at least three years.

- Action Items: Academic divisions/departments of EM should establish reward, recognition and support models that take into consideration career stage.

- Action Item: The Academic Section should establish national metrics for productivity in EM scholarship, including definitions of outcomes, measures of quality, measures of impact, and quantification of contributions.

\section{FOLLOW UP}

3. The Academic Section should review and monitor the implementation of these recommendations.

- Action Item: The Academic Section should provide all academic divisions/ departments of EM a confidential biyearly report card indicating their achievements in the development of education scholars, the support of education scholars, the quantity of education scholarship produced and the quality of education scholarship produced.

- Action Item: The Academic Section should report back to the CAEP membership in 2015 and 2018 regarding progress in achieving these recommendations.

\section{CONCLUSION}

EM is already recognized for excellence in clinical care and clinical teaching. EM has the potential to be a leader in education scholarship. Success requires the EM community to systematically make education scholarship a priority by providing training for emerging scholars and support for scholarship via mentorship, protected time, and operational resources.

Competing interests: None declared.

\section{REFERENCES}

1. Boyer E. Scholarship reconsidered: priorities for the professoriate. Princeton (NJ): The Carnegie Foundation for the Advancement of Teaching; 1990.
2. Glassick CE. Boyer's expanded definitions of scholarship, the standards for assessing scholarship, and the elusiveness of the scholarship of teaching. Acad Med 2000;75:877-80, doi:10.1097/00001888-200009000-00007.

3. Dirks AL. The new definition of scholarship: how will it change the professoriate? Available at: http://webhost.bridgew.edu/ adirks/ald/papers/skolar.htm (accessed September 2013).

4. Hutchings $P$, Shulman LS. The scholarship of teaching: new elaborations, new developments. Change 1999;31(5:10-5, doi:10.1080/00091389909604218.

5. van Melle E, Curren V, Goldszmidt M, et al. Toward a common understanding: advancing education scholarship for clinical faculty in Canadian medical schools. Ottawa: Canadian Association for Medical Education; 2013.

6. Sherbino J, van Melle E, Bandiera G, et al. Education scholarship in emergency medicine part 1: innovating and improving teaching and learning. CFEM 2014;16:00-00.

7. Atzema C, Bandiera G, Schull M. Emergency department crowding: the effect on resident education. Ann Emerg Med 2005;45:276-81, doi:10.1016/j.annemergmed.2004.12.011.

8. Bandiera G, Lee S, Tiberius R. Creating effective learning in today's emergency departments: how accomplished teachers get it done. Ann Emerg Med 2005;45:253-61, doi:10.1016/ j.annemergmed.2004.08.007.

9. Burdick WP, Schoffstall J. Observation of emergency medicine residents at the bedside: how often does it happen? Acad Emerg Med 1995;2:909-13, doi:10.1111/j.15532712.1995.tb03108.x

10. Chisholm CD, Whenmouth LF, Daly EA, et al. An evaluation of emergency medicine resident interaction time with faculty in different teaching venues. Acad Emerg Med 2004;11:149-55, doi:10.1111/j.1553-2712.2004.tb01425.x.

11. Yarris L, Coates W. Creating educational leaders: experiences with two education fellowships in emergency medicine. Acad Emerg Med 2012;19:1481-5, doi:10.1111/acem. 12042.

12. Coates WC, Lin M, Clarke S, et al. Defining a core curriculum for education scholarship fellowships in emergency medicine. Acad Emerg Med 2012;19:1411-8, doi:10. 1111/acem.12036.

13. Lin M, Santen SA, Yarris LM, et al. Development of a training needs assessment for an education scholarship fellowship in emergency medicine. Acad Emerg Med 2012; 19:1419-24, doi:10.1111/acem.12035.

14. The future of medical education in Canada (FMEC): a collective vision for MD education. Ottawa: Association of Faculties of Medicine of Canada; 2010.

15. The future of medical education in Canada: postgraduate project. Ottawa: Faculties of Medicine of Canada, Royal College of Physicians and Surgeons of Canada, College of Family Physicians of Canada, Collège Des Médecins Du Québec; 2012.

16. Tannenbaum D, Kerr J, Konkin J, et al. Triple C competencybased curriculum. Report of the Working Group on Postgraduate Curriculum Review - Part 1. Mississauga (ON): College of Family Physicians of Canada; 2011.

17. Anderson T, Shattuck J. Design-based research: a decade of progress in education research? Educ Res 2012;41:16-25, doi:10.3102/0013189X11428813. 
18. Dolmans DHJM, Tigelaar D. Building bridges between theory and practice in medical education using a designbased research approach: AMEE guide no. 60. Med Teach 2012;34:1-10, doi:10.3109/0142159X.2011.595437.

19. Nisbet $J$. What is education research? Changing perspectives through the 21th century. Res Papers Educ 2005;20(1):25-44, doi:10.1080/0267152052000341327.

20. Bessman SC, Agada NO, Ding R, et al. Comparing National Institutes of Health funding of emergency medicine to four medical specialties. Acad Emerg Med 2011;18:1001-4, doi:10.1111/j.1553-2712.2011.01138.x.

21. Arnold L. Preface: case studies of medical education research groups. Acad Med 2004;79:966-8, doi:10.1097/00001888200410000-00015.

22. Collins J. Medical education research: challenges and opportunities. Radiology 2006;240:639-47, doi:10.1148/ radiol.2403050542.

23. Chandran L, Gusic M, Baldwin C, et al. Evaluating the performance of medical educators: a novel analysis tool to demonstrate the quality and impact of educational activities. Acad Med 2009;84:58-66, doi:10.1097/ACM.0b013e31819 $045 \mathrm{e} 2$.

24. Beasly BW, Wright SM, Corancesoc J, et al. Promotion criteria or clinician educators in the US and Canada. $7 A M A$ 1997;278:723-8, doi:10.1001/jama.1997.03550090047031.

25. Atasovlu AA, Wright SM, Beasly BW, et al. Promotion criteria for clinician-educators. 7 Gen Intern Med 2003;18: 711-6, doi:10.1046/j.1525-1497.2003.10425.x.

26. Love JN, Coates WC, Santen SA, et al. The MERC at CORD scholars program in medical education research: a novel faculty development opportunity for emergency physicians. Acad Emerg Med 2009;16 Suppl 2:S37-51, doi:10. $\underline{1111 / \mathrm{j} .1553-2712.2009 .00591 . x}$.

27. Hillier M, McLeod S, Mendelsohn D, et al. Emergency medicine training in Canada: a survey of medical students' knowledge, attitudes, and preferences. CFEM 2011;13:251-8.

28. Varner C, Ovens H, Letovsky E, et al. Practice patterns of graduates of a CCFP(EM) residency program: a survey. Can Fam Physician 2012;58:e385-9.

29. Taylor JT, Friedman RH, Speckman JL, et al. Fellowship training and career outcomes for primary care physicianfaculty. Acad Med 2001;76:366-72, doi:10.1097/00001888200104000-00015.

30. Anderson KD, Mavis BE. The relationship between career satisfaction and fellowship training in academic surgeons. Am 7 Surg 1995;169:329-33, doi:10.1016/S0002-9610(99) 80169-X.

31. Burkhardt J, Kowalenko T, Meurer W. Academic career selection in American emergency medicine residents. Acad Emerg Med 2011;18 Suppl 2:S48-53, doi:10.1111/j.15532712.2011.01181.x.

32. Theoret J, Sanz G, Cheng A, et al. The evolution of emergency medicine: the pressing need for "made in Canada" subspecialty training. CFEM 2011;13:416-20.

33. Coates WC, Hobgood CD, Birnbaum A, et al. Faculty development: academic opportunities for emergency medicine faculty on education career tracks. Acad Emerg Med 2003;10:1113-7, doi:10.1111/j.1553-2712.2003.tb00584.x.
34. Bandiera G, Lee S, Foote J. Faculty perceptions and practice impact of a faculty development workshop on emergency medicine teaching. CFEM 2005;7:321-7.

35. Khandelwal S, Bernard AW, Wald DA, et al. Developing and assessing initiatives designed to improve clinical teaching performance. Acad Emerg Med 2012;19:1350-3, doi:10. 1111/acem.12029.

36. Ratnapalan S. Knowledge to action: scholarship for faculty and staff. 7 Contin Educ Health Prof 2009;29:32-8, doi:10. 1002/chp.20003.

37. Farley H, Casaletto J, Ankel F, et al. An assessment of the faculty development needs of junior clinical faculty in emergency medicine. Acad Emerg Med 2008;15:664-8, doi:10.1111/j.1553-2712.2008.00152.x.

38. Whitcomb ME. Research in medical education: what do we know about the link between what doctors are taught and what they do? Acad Med 2002;77:1067-8, doi:10.1097/ 00001888-200211000-00001.

39. Lewis RJ. Educational research: time to raise the bar not lower it. Acad Emerg Med 2005;12:247-8, doi:10.1111/j. 1553-2712.2005.tb00878.x.

40. Gruppen L. Improving medical education research. Teach Learn Med 2007;19:331-5, doi:10.1080/10401330701542 370 .

41. Cook DA, Beckman TJ, Bordage G. Quality of reporting of experimental studies in medical education: a systematic review. Med Educ 2007;41:737-45, doi:10.1111/j.13652923.2007.02777.x.

42. LaMantia J, Hamstra SJ, Martin DR, et al. Faculty development in medical education research. Acad Emerg Med 2012;19:1462-7, doi:10.1111/acem.12037.

43. Aagaard EM, Hauer KE. A cross-sectional descriptive study of mentoring relationships formed by medical students. 7 Gen Intern Med 2003;18:298-302, doi:10.1046/j.15251497.2003.20334.x.

44. Benson CA, Morahan PS, Sachdeva AK, et al. Effective faculty preceptoring and mentoring during reorganization of an academic medical center. Med Teach 2002;24:550-7, doi: 10.1080/0142159021000002612.

45. Castiglioni A, Bellini LM, Shea JA. Program directors' views of the importance and prevalence of mentoring in internal medicine residencies. F Gen Intern Med 2004;19:779-82, doi:10.1111/j.1525-1497.2004.30169.x.

46. Donovan A, Donovan J. Mentorship in postgraduate training programmes: views of Canadian programme directors. Med Educ 2009;43:155-8, doi:10.1111/j.1365-2923.2008.03258.x.

47. Levy BD, Katz JT, Wolf MA, et al. An initiative in mentoring to promote residents' and faculty members' careers. Acad Med 2004;79:845-50, doi:10.1097/00001888200409000-00006.

48. Palepu A, Friedman RH, Barnett RC, et al. Junior faculty members' mentoring relationships and their professional development in U.S. medical schools. Acad Med 1998;73: 318-23, doi:10.1097/00001888-199803000-00021.

49. Ramanan RA, Taylor WC, Davis RB, et al. Mentoring matters - mentoring and career preparation in internal medicine residency training. 7 Gen Intern Med 2006;21:3405, doi:10.1111/j.1525-1497.2006.00346.x.

50. Ricer RE, Fox BC, Miller KE. Mentoring for medical students interested in family practice. Fam Med 1995;27:360-5. 
51. Connor MP, Bynoe AG, Redfern N, et al. Developing senior doctors as mentors: a form of continuing professional development: report of an initiative to develop a network of senior doctors as mentors: 1994-1999. Med Educ 2000;34: 747-53, doi:10.1046/j.1365-2923.2000.00630.x.

52. Boyd JS, Clyne B, Reinert SE, et al. Emergency medicine career choice: a profile of factors and influences from the Association of American Medical Colleges (AAMC) graduation questionnaires. Acad Emerg Med 2009;16:544-9, doi:10.1111/j.1553-2712.2009.00385.x

53. Schrader C, Barsan WG, Gordon JA, et al. Scholarship in emergency medicine in an environment of increasing clinical demand: proceedings from the 2007 Association of American Medical Colleges annual meeting. Acad Emerg Med 2008;15: 567-72, doi:10.1111/j.1553-2712.2008.00118.x.

54. CIHR benchmarks. Available at: https://www.researchnet recherchenet.ca/rnr16/vwOpprtntyDtls.do?prog $=1709 \&$ view $=$ currentOpps\&org $=$ CIHR \& type $=$ EXACT $\&$ resultCount $=$ $25 \&$ sort $=$ program \&all $=1 \&$ masterList $=$ true $($ accessed September 2013).

55. Department of Medicine, University of Toronto. Institutional job descriptions, e.g. University of Toronto Department of Medicine EM job descriptions. Available at: http://www.deptmedicine. utoronto.ca/Faculty/appointments/emjob.htm (accessed September 2013).
56. Kapur PA. The impact of new-generation physicians on the function of academic anesthesiology departments. Curr Opin Anaesthesiol 2007;20:564-7, doi:10.1097/ACO.0b013e328 $2 \mathrm{f} 0 \mathrm{ef} 75$.

57. Mohr NM, Smith-Coggins R, Larrabee H, on behalf of the Society for Academic Emergency Medicine Aging and Generational Issues in Academic Emergency Medicine Task Force. Generational influences in academic emergency medicine: structure, function, and culture (part II). Acad Emerg Med 2011;18:200-7, doi:10.1111/j.1553-2712.2010. 00986.x.

58. Trower CA. Making academic dentistry more attractive to new teacher-scholars. 7 Dent Educ 2007;71:601-5.

59. Madariaga MG, Evans AT, Brobbey W, et al. Learning by doing: developing fellows' academic skills through collaborative research. Med Teach 2006;28:77-80, doi:10.1080/ 01421590500138804.

60. Pati S, Reum J, Conant E, et al. Tradition meets innovation: transforming academic medical culture at the University of Pennsylvania's Perelman School of Medicine. Acad Med 2013;88:461-4, doi:10.1097/ACM.0b013e3182857f67.

61. Sherbino J. Education scholarship: the next step for our specialty. CFEM 2010;12:347-8. 